\title{
Parameters affecting the synthesis of $\beta$-tricalcium phosphate powder using a wet precipitation method
}

\author{
R. Othman ${ }^{1}$, Z. Mustafa ${ }^{1 *}$, P.T. Kien ${ }^{2}$, N.F. Ishak ${ }^{1}$, A. Shaaban ${ }^{1}$ and A.F. Mohd \\ Noor $^{2}$ \\ ${ }^{1}$ Advanced Manufacturing Centre, Faculty of Manufacturing Engineering, \\ Universiti Teknikal Malaysia Melaka, 76100 Durian Tunggal, Malacca, Malaysia \\ *Email: zaleha@utem.edu.my \\ Phone: +6063316533; Fax: +6063316431 \\ ${ }^{2}$ School of Materials \& Mineral Resources Engineering, Universiti Sains Malaysia, \\ Engineering Campus, 14300 Nibong Tebal, Penang, Malaysia
}

\begin{abstract}
In this work, precursor materials that are normally used to directly synthesise hydroxyapatite (HA) were adopted to obtain tricalcium phosphate (TCP). Calcium hydroxide, $\left(\mathrm{Ca}(\mathrm{OH})_{2}\right)$, and phosphoric acid, $\left(\mathrm{H}_{3} \mathrm{PO}_{4}\right)$, with a $\mathrm{Ca} / \mathrm{P}$ ratio of 1.5 , were mixed as the precursor materials. The mixture was stirred at various stirring speeds ranging from 0 to $400 \mathrm{rpm}$, over a range of stirring durations of 1 to 4 hours. Upon completion of the reaction, the as-prepared powders were calcined at different temperatures ranging from $500^{\circ} \mathrm{C}-1300^{\circ} \mathrm{C}$ for a soaking duration that was varied between 1-4 hours. Differential scanning calorimetry (DSC) and thermogravimetry (TG) were used for thermal analyses to ascertain the calcination temperatures, whilst $\mathrm{x}$-ray diffraction (XRD) was utilised to determine the phases formed before and after calcination. Field emission scanning electron microscopy (FESEM) was used to monitor the morphological changes at different calcination temperatures. Based on the XRD results, the phases formed were dependent on the processing parameters employed. This work has successfully ascertained that the most optimum parameters to synthesise singlephase $\beta$-TCP are a stirring speed of $200 \mathrm{rpm}$, a calcination temperature of $900^{\circ} \mathrm{C}$, a calcination soaking duration of 2 hours and a mixing duration of 1 hour. Microstructural observation conducted on the $\beta$-TCP powders obtained at calcination temperatures of $900^{\circ} \mathrm{C}$ to $1300^{\circ} \mathrm{C}$ showed an aggregated structure of particles with massive grain growth as the temperature was raised up to $1300^{\circ} \mathrm{C}$.
\end{abstract}

Keywords: Hydroxyapatite; monetite; tricalcium phosphate; calcination.

\section{INTRODUCTION}

Biomaterials are a new group of functional materials that have emerged and exhibited a prolific growth to fulfil the demands in the fields of medicine and dentistry. Over the past few decades, new biomaterials for bone replacement, total hip prosthesis and dental implants have been synthesised and commercialised for various needs. Currently, thousands of these materials can be found easily in the market. The world market for orthopaedic biomaterials is worth over US\$25 billion in 2006 and has a growth rate of more than $5 \%$ a year. The market for orthopaedic biomaterials is expected to increase each year due to the need for better solutions for injuries, diseases and the ageing 
population all over the world. The orthopaedic biomaterials market consists primarily of bone graft substitutes, bone growth factors, degradable tissue fixation and tissue technologies for cartilage regeneration. Generally, orthopaedic prostheses should offer a functional life of at least 20 years to match the life span of most patients. This presents a considerable problem for most orthopaedic biomaterials [1]. In Malaysia, research works on orthopaedic biomaterials, especially on bone graft and degradable materials, are still in the infancy stage. Up to now, Malaysia has spent more than RM20 million each year to purchase synthetic bone grafts from foreign countries such as Switzerland, Germany and the United States. Therefore, the Malaysian government intends to produce bone grafts of its own with the supporting research from Universiti Sains Malaysia (USM), the Malaysian Institute for Nuclear Technology Research (MINT), Universiti Kebangsaan Malaysia (UKM) and International Islamic University Malaysia (IIUM) (Material Medical Malaysian website, 2006). Synthetic bone graft materials such as ceramics, polymers and metals are introduced as alternatives to the traditional bone substitutes. Among these materials, calcium phosphate ceramics such as hydroxyapatite (HA) and $\beta$ tricalcium phosphate ( $\beta$-TCP) are the most suitable materials with excellent biological properties [2]. To date, there is still a limited number of research on the synthesis of $\beta$ TCP. Generally, $\beta$-TCP is prepared using a solid-state reaction or a wet chemical reaction. The solid-state reaction was reported by several researchers [3-5], whilst the wet chemical reaction was carried out in a handful of studies [6-9]. However, these synthesised $\beta$-TCP powders were not stable in terms of its thermal properties whereby they were converted to $\alpha$-TCP at temperatures above $1125^{\circ} \mathrm{C}$ [5]. In terms of starting materials, the present research modified the study used by Cheang and Khor [10] and other researchers [11-13] to synthesise $\beta$-TCP. According to Afshar and his co-workers [11, 12], HA can be synthesised using the system of $\mathrm{Ca}(\mathrm{OH})_{2}$ and $\mathrm{H}_{3} \mathrm{PO}_{4}$ with a $\mathrm{Ca} / \mathrm{P}$ ratio of 1.67 . This reaction was expected to be developed as an industrial-scale method to produce HA with the correct stoichiometric composition according to the Eq. (1):

$$
10 \mathrm{Ca}(\mathrm{OH})_{2}+6 \mathrm{H}_{3} \mathrm{PO}_{4} \rightarrow \mathrm{Ca}_{10}\left(\mathrm{PO}_{4}\right)_{6}(\mathrm{OH})_{2}+18 \mathrm{H}_{2} \mathrm{O}
$$

In the present research work, a wet chemical reaction such as the precipitation method was carried out to prepare $\beta$-TCP. Instead of using a $\mathrm{Ca} / \mathrm{P}$ ratio of 1.67 , a modification was attempted whereby $\mathrm{Ca}(\mathrm{OH})_{2}$ and $\mathrm{H}_{3} \mathrm{PO}_{4}$ were used as the starting materials with a $\mathrm{Ca} / \mathrm{P}$ ratio of 1.5 . The mechanism of phase transformation in this synthesis method was fully explored. In a wet precipitation method, there are a number of process parameters such as the composition of starting materials, stirring speed, stirring duration, calcination temperature and calcination soaking duration. Therefore, the objectives of this research is to synthesise single-phase $\beta$-TCP powders using a wet precipitation method and starting materials that have not been attempted before by optimising the reaction parameters (stirring speed, stirring duration) and calcination conditions (calcination temperature, soaking time) to form a single phase $\beta$-TCP. The mechanism of the phase transformation upon calcination as well as the morphology and thermal stability of the $\beta$-TCP powder so-produced will be studied as well.

\section{MATERIALS AND METHODS}

\section{Wet Precipitation Method}

The starting materials used to produce $\beta$-TCP powders in this work include calcium hydroxide, $\mathrm{Ca}(\mathrm{OH})_{2}\left(96 \%\right.$ purity, FLUKA, 21181, UK) and phosphoric acid $\mathrm{H}_{3} \mathrm{PO}_{4}$ (15M, MERCK, 100573, Germany). Two solutions were prepared to synthesise $\beta$-TCP, 
namely a 0.30 mole phosphoric acid solution and a 0.45 mole calcium hydroxide solution. $100 \mathrm{ml}$ of 0.45 mole phosphoric acid was pipetted slowly into $300 \mathrm{ml}$ of 0.30 mole calcium hydroxide solution. The mole ratio of $\mathrm{Ca}(\mathrm{OH})_{2}$ to $\mathrm{H}_{3} \mathrm{PO}_{4}$ was 1.5 based on the $\beta$ TCP stoichiometric composition. The reaction was performed in a water bath (Elma, Transsonic T660 model, UK) set at $70^{\circ} \mathrm{C}$ to control the temperature of the reactants. During the reaction, the suspension was unstirred as well as stirred at different stirring speeds of $100 \mathrm{rpm}, 200 \mathrm{rpm}, 300 \mathrm{rpm}$ and $400 \mathrm{rpm}$ (labelled as S0, S100, S200, S300 and S400, respectively) for 2 hours, and this stirring duration was later varied to 1 hour, 3 hours and 4 hours by using a stirring machine (KILA, RW20DZM model, Germany). The $\mathrm{pH}$ of the mixture before and after the reaction was also monitored using a $\mathrm{pH}$ meter (Eutech brand, LH7 model, UK). After the reaction had completed, the mixture was filtered and washed twice with $50 \mathrm{ml}$ distilled water.

\section{Drying and Calcination of As-Prepared Powders}

Subsequently, the wet powder was dried in an oven (Binder, UK) at $100^{\circ} \mathrm{C}$ for 24 hours before being ground into a fine powder (thereafter referred to as-prepared powder) using an agate pestle and mortar. About 0.2 gram of the powder was sampled for thermal analysis (Netzsch, STA 409 PC Luxx) to determine the most suitable calcination temperature to be used. Based on these results, the as-prepared powders were calcined at $500^{\circ} \mathrm{C}, 700^{\circ} \mathrm{C}, 900^{\circ} \mathrm{C}, 1000^{\circ} \mathrm{C}, 1100^{\circ} \mathrm{C}, 1200^{\circ} \mathrm{C}$ and $1300^{\circ} \mathrm{C}$ for a soaking duration of 2 hours, which was later varied to 1, 3 and 4 hours. The powders were characterised using $\mathrm{XRD}$ for phase identification. The powders that were calcined over $900^{\circ} \mathrm{C}-1300^{\circ} \mathrm{C}$ were observed using the FESEM to elucidate any morphological changes.

\section{X-ray Diffraction of Uncalcined and Calcined Powders}

The as-prepared powders produced from the wet precipitation method using, firstly, different mixing speeds were analysed using X-ray diffraction before calcination. Then, these powders produced from five different mixing speeds of 0, 100, 200, 300 and 400 rpm were also analysed using XRD after calcination. From these observations, it became apparent that the S200 and S300 powders were most suited for detailed investigation at different calcination temperatures of $500^{\circ} \mathrm{C}, 700^{\circ} \mathrm{C}, 900^{\circ} \mathrm{C}, 1000^{\circ} \mathrm{C}, 1100^{\circ} \mathrm{C}, 1200^{\circ} \mathrm{C}$ and $1300^{\circ} \mathrm{C}$. Consequently, the lowest temperature to calcine the as-prepared powder and the optimum mixing speed during the wet precipitation method were ascertained. Using the established parameters of 200 mixing speed and $900^{\circ} \mathrm{C}$ calcination temperature, the minimum duration of mixing was subsequently established.

\section{Effect of Different Calcination Soaking and Mixing Durations}

Once the optimum mixing speed and calcination temperature had been ascertained, the S200 powder was calcined at different soaking durations before the phases obtained were analysed using XRD. Similarly, the S200 powders mixed for various mixing duration of $1,2,3$ and 4 hours were calcined for 1 hour at $900^{\circ} \mathrm{C}$ before analysed using XRD.

\section{RESULTS AND DISCUSSION}

\section{Thermal Analysis Using DSC/TG}

All five as-prepared powders produced at different stirring speeds, S0, S100, S200, S300, and S400 were analysed using DSC/TG. From Figure 1, a small endotherm (and weight loss) was observed for all at $100^{\circ} \mathrm{C}$ (due to adsorbed water), a second endotherm (and weight losses) at about $450^{\circ} \mathrm{C}$ for S0-S300 except for S400, and a third weight loss (with 
no noticeable endotherm) at $600-900^{\circ} \mathrm{C}$ for all five powders. The second endothermic peak at $450^{\circ} \mathrm{C}$ is attributed to the decomposition of monetite into dicalcium phosphate $\left[D C P, \mathrm{Ca}_{2} \mathrm{P}_{2} \mathrm{O}_{7}\right]$ as reported in [14]. The presence of monetite and DCP is confirmed by $\mathrm{XRD}$. The areas under these endothermic peaks decrease with increasing stirring speeds. Similarly, the weight losses on the TG curves corresponding to these peaks also decrease with increasing stirring speeds, indicating that the amount of compound decomposed also decreases (Table 1). The weight loss between $600^{\circ} \mathrm{C}$ to $900^{\circ} \mathrm{C}$ can be observed clearly in the five samples, indicating the decomposition of HA into $\beta$-TCP. Since these endothermic peaks and/or weight losses were observed around $600^{\circ} \mathrm{C}-900^{\circ} \mathrm{C}$, the XRD patterns of the as-prepared powders, calcined at $900^{\circ} \mathrm{C}$, were also determined so as to unravel the reactions that took place. The possible reactions postulated in Table 1 are based on the work by [14-16]. However, this will be confirmed through XRD.

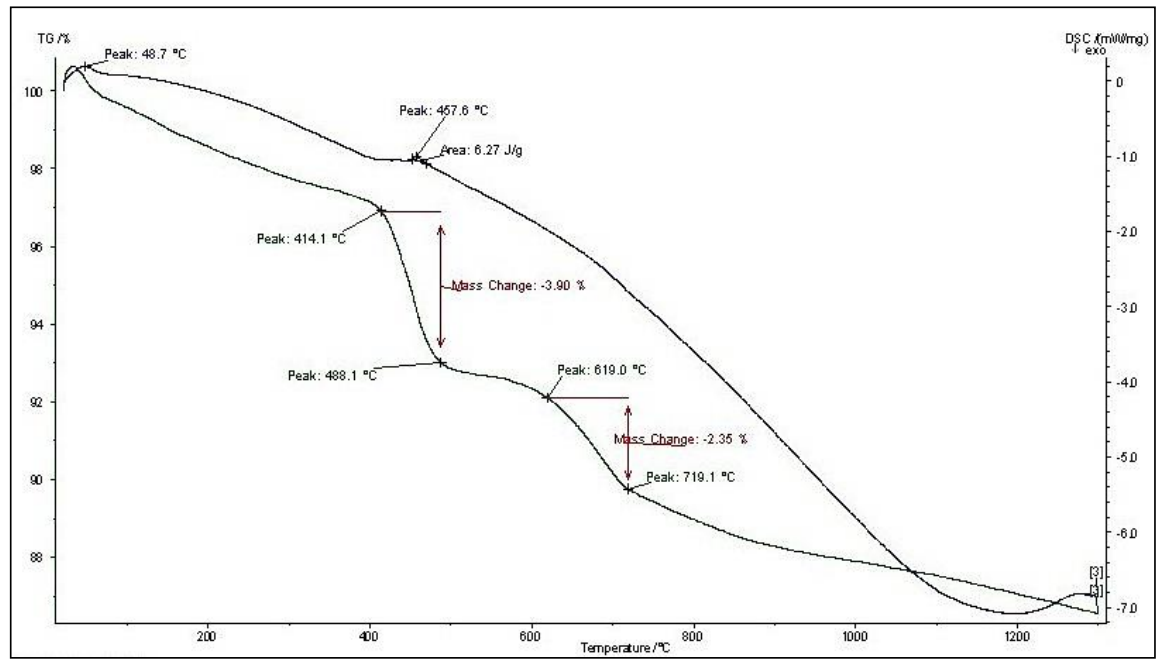

Figure 1. DSC/TG Curves for As-Prepared Powder S100

Table 1. DSC/TG Results for As-Prepared S0, S100, S200, S300 and S400 Powders

\begin{tabular}{|c|c|c|c|c|c|c|}
\hline & $\begin{array}{l}1^{\text {st }} \mathrm{TG} \\
\text { Peak }\end{array}$ & $\begin{array}{l}\text { Weight } \\
\text { loss }\end{array}$ & $2^{\text {nd }}$ TG Peak & Weight loss & $3^{\text {rd }}$ TG Peak & Weight loss \\
\hline S0 & 50.8 & 0.7 & 456 & 5.7 & - & 1.9 \\
\hline S100 & 48.7 & 0.6 & 458 & 3.9 & - & 2.4 \\
\hline S200 & 58.0 & 2.1 & 455 & 0.9 & - & 1.0 \\
\hline S300 & 53.3 & 1.3 & 449 & 1.1 & - & 1.0 \\
\hline S400 & 42.1 & 0.8 & $\begin{array}{c}\text { No peak } \\
\text { discernible }\end{array}$ & Not obvious & - & 0.6 \\
\hline Note: & $\begin{array}{l}\text { endo- } \\
\text { thermic }\end{array}$ & $\begin{array}{c}\text { loss of } \\
\text { adsorbed } \\
\text { water }\end{array}$ & $\begin{array}{l}\text { endo-thermic } \\
\text { peak not } \\
\text { discernible }\end{array}$ & $\begin{array}{l}\text { decomposition of } \\
\text { monetite to DCP }\end{array}$ & $\begin{array}{l}\text { TG peak not } \\
\text { discernible }\end{array}$ & $\begin{array}{l}\text { decompose of } \\
\text { HA to } \beta \text {-TCP }\end{array}$ \\
\hline
\end{tabular}

\section{Phases Formed as a Consequence of Variable Stirring Speeds}

The as-prepared powders mixed at various speeds were analysed using XRD and the results are shown in Table 2. At mixing speeds of 0 and $100 \mathrm{rpm}$, the as-prepared powders consist of monetite $\left(\mathrm{CaHPO}_{4}\right)$ and calcium hydroxide, $\left(\mathrm{Ca}(\mathrm{OH})_{2}\right)$. As the mixing speed 
was increased to 200 and $300 \mathrm{rpm}$, the phases formed are monetite and hydroxyapatite $\left(\mathrm{Ca}_{10}\left(\mathrm{PO}_{4}\right)_{6}(\mathrm{OH})_{2}\right)$. At the highest mixing speed, the phase detected by XRD is HA of poor crystallinity as exhibited by the diffused broad peaks. Based on the premise that at temperatures above $900^{\circ} \mathrm{C}$, no further weight loss or reactions were observed on the DSC/TG curves, a temperature of $900^{\circ} \mathrm{C}$ was chosen to calcine the various powders produced at different mixing speeds of 0-400 rpm. Table 2 shows that powders S0, S100 and S400 exhibit a mixture of phases after calcination, whilst only those of S200 and S300 exhibit single-phase $\beta$-TCP.

Table 2. Phases of As-Prepared and Calcined $\left(900^{\circ} \mathrm{C}\right)$ Powders as Determined Using XRD.

\begin{tabular}{ccc}
\hline Mixing Speed Code & As-prepared powders & Powders calcined at $900{ }^{\circ} \mathrm{C}$ \\
\hline S0 & Monetite $+\mathrm{Ca}(\mathrm{OH})_{2}$ & $\beta$-TCP $+\mathrm{HA}$ \\
S100 & Monetite $+\mathrm{Ca}(\mathrm{OH})_{2}$ & $\beta$-TCP $+\mathrm{HA}$ \\
S200 & Monetite $+\mathrm{HA}$ & $\beta$-TCP \\
S300 & Monetite $+\mathrm{HA}$ & $\beta$-TCP \\
S400 & HA with low degree of & $\beta-\mathrm{TCP}+\mathrm{HA}+\mathrm{CaO}$ \\
& crystallinity & \\
\hline
\end{tabular}

From these observations, it can be concluded that $\mathrm{Ca}(\mathrm{OH})_{2}$ had not reacted completely with $\mathrm{H}_{3} \mathrm{PO}_{4}$ at the stirring speeds of 0 and $100 \mathrm{rpm}$ and had still remained in the as-prepared powder (Table 2). Consequently, the reaction between $\mathrm{Ca}(\mathrm{OH})_{2}$ and $\mathrm{H}_{3} \mathrm{PO}_{4}$ at low stirring speed does not follow stoichiometric reaction. However, when the speed of stirring was increased to $200 \mathrm{rpm}$ and $300 \mathrm{rpm}$, the XRD patterns of the asprepared S200 and S300 powders no longer show the presence of $\mathrm{Ca}(\mathrm{OH})_{2}$. Hence, it can be concluded that $\mathrm{Ca}(\mathrm{OH})_{2}$ had reacted completely with $\mathrm{H}_{3} \mathrm{PO}_{4}$ at these two higher stirring speeds to produce a mixture phase of monetite and HA in the as-prepared powders (Table 2). Eqs. (2) and (3) describe the formation of monetite and HA from the reaction between the precursor or starting materials $\mathrm{Ca}(\mathrm{OH})_{2}$ and $\mathrm{H}_{3} \mathrm{PO}_{4}$. The direct precipitates from $\mathrm{Eq}(2)$ and Eq. (3) are monetite and HA. In other words, this work confirms the conclusion of previous studies $[9,17]$ which stated that $\beta$-TCP cannot be precipitated directly from an aqueous solution.

$$
\begin{aligned}
& \mathrm{Ca}(\mathrm{OH})_{2}+\mathrm{H}_{3} \mathrm{PO}_{4} \rightarrow \mathrm{CaHPO}_{4}+2 \mathrm{H}_{2} \mathrm{O} \\
& 10 \mathrm{Ca}(\mathrm{OH})_{2}+6 \mathrm{H}_{3} \mathrm{PO}_{4} \rightarrow \mathrm{Ca}_{10}\left(\mathrm{PO}_{4}\right)_{6}(\mathrm{OH})_{2}+18 \mathrm{H}_{2} \mathrm{O}
\end{aligned}
$$

It is also enumerated in Table 2 that the phases that are formed when these powders ( $\mathrm{S} 200$ and $\mathrm{S} 300$ ) were calcined at $900^{\circ} \mathrm{C}$ for 2 hours produce $\beta$-TCP (ICDD 9169 ) with a $\mathrm{Ca} / \mathrm{P}$ ratio $=1.5$. A similar finding based on a solid-state reaction was reported by Yoshida [5] where he found that if a mixture of $\mathrm{CaHPO}_{4}$ and $\mathrm{HA}$ with a $\mathrm{Ca} / \mathrm{P}$ ratio of 1.5 was calcined at $1100^{\circ} \mathrm{C}$ for 24 hours, a single-phase $\beta$-TCP could be obtained. Indirectly, this work has successfully proven that a single phase $\beta$-TCP can be produced at a much lower calcination temperature of $900^{\circ} \mathrm{C}$ (compared to $1100^{\circ} \mathrm{C}$ ) and a much shorter soaking duration of 2 hours (as compared to 24 hours). The XRD analysis of the as-prepared S400 powder shows a single-phase HA with a low degree of crystallinity formed (Table 2) which is in accordance to Eq. (3). The partial decomposition of HA into $\beta$-TCP at $900^{\circ} \mathrm{C}$ with the remnants of $\mathrm{HA}$ and $\mathrm{CaO}$ according to Eq. (4) was reported in literatures $[15,16]$. 


$$
\mathrm{Ca}_{10}\left(\mathrm{PO}_{4}\right)_{6}(\mathrm{OH})_{2} \underset{\Delta}{\longrightarrow} 3 \beta-\mathrm{Ca}_{3}\left(\mathrm{PO}_{4}\right)_{2}+\mathrm{CaO}+\mathrm{H}_{2} \mathrm{O}
$$

In summary, the stirring speed plays an important role in the synthesis of $\beta$-TCP. Since $\beta$-TCP cannot be precipitated directly from an aqueous solution, i.e. the direct product of the reaction between $\mathrm{Ca}(\mathrm{OH})_{2}$ and $\mathrm{H}_{3} \mathrm{PO}_{4}$ depends on the mobility and the diffusion of $\mathrm{Ca}^{2+}, \mathrm{PO}_{4}{ }^{3-}, \mathrm{H}^{+}$and $\mathrm{OH}^{-}$ions which are influenced by the stirring speed. Table 2 summarises the phase(s) in the as-prepared powders at different stirring speeds and the corresponding powders calcined at $900^{\circ} \mathrm{C}$. Thus, it can be summarised that stirring speeds of 200 and $300 \mathrm{rpm}$ as well as a calcination temperature of $900^{\circ} \mathrm{C}$ for 2 hours soaking duration are successful in producing a single-phase $\beta$-TCP.

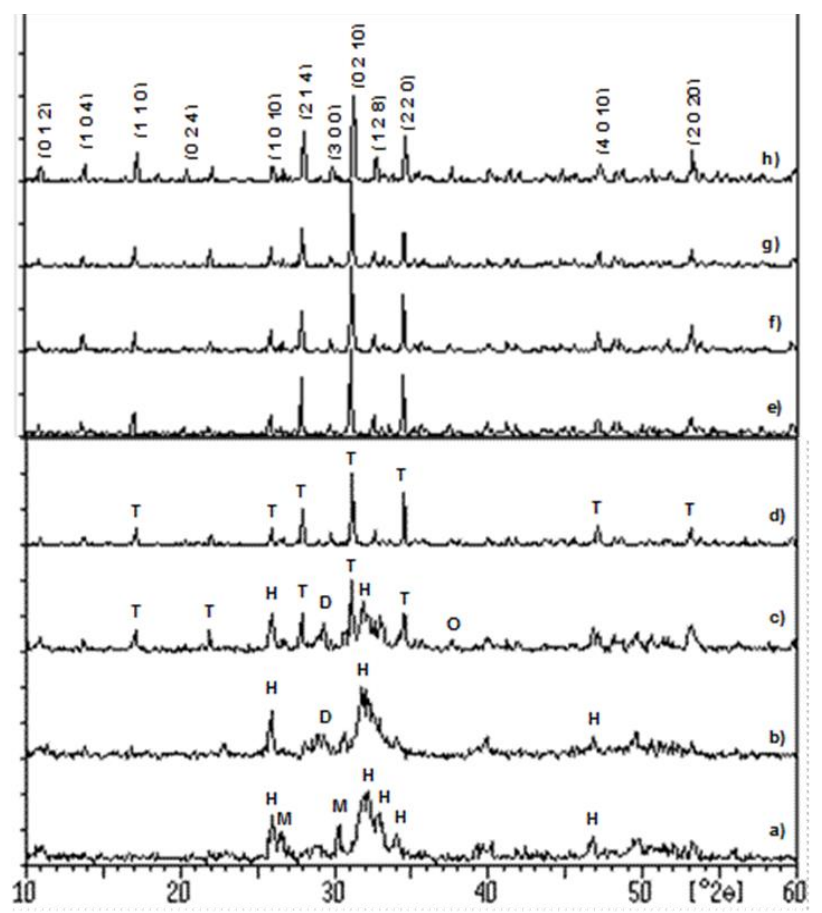

Figure 2. XRD patterns of S200 powders before and after calcination at different temperatures for 2 hours soaking (a) as-prepared powder, (b) $500^{\circ} \mathrm{C}$, (c) $700^{\circ} \mathrm{C}$, (d) $900^{\circ} \mathrm{C}$, (e) $1000^{\circ} \mathrm{C}$, (f) $1100^{\circ} \mathrm{C}$, (g) $1200^{\circ} \mathrm{C}$, and (h) $1300^{\circ} \mathrm{C}$. [H - HA; M - Monetite; D $-\beta$-DCP; T- $\beta$-TCP; $\mathrm{O}-\mathrm{CaO}$.

\section{Phases Formed as a Function of Calcination Temperatures}

From the preceding observations using DSC/TG and XRD, the as-prepared powder produced at $200 \mathrm{rpm}$ (S200) was deemed to be the best powder for further calcination studies. Hence, S200 powders before and after calcination at various temperatures of $500^{\circ} \mathrm{C}, 700^{\circ} \mathrm{C}, 900^{\circ} \mathrm{C}, 1000^{\circ} \mathrm{C}, 1100^{\circ} \mathrm{C}, 1200^{\circ} \mathrm{C}$ and $1300^{\circ} \mathrm{C}$ were subsequently analysed using XRD and the results are shown in Figure 2. Powders calcined at $500^{\circ} \mathrm{C}$ and $700^{\circ} \mathrm{C}$ still display remnants from the precursor phase (HA) as well as intermediate phases (DCP, $\mathrm{HA}, \mathrm{CaO}$ ). From these results, it can be observed that a single-phase $\beta$-TCP can successfully be produced at a calcination temperature of as low as $900^{\circ} \mathrm{C}$. This is much lower than the $1100^{\circ} \mathrm{C}$ reported earlier [5]. This phase remains thermally stable even up to $1300^{\circ} \mathrm{C}$ which is much higher than those reported in previous works, viz. $1120^{\circ} \mathrm{C}$ $1170^{\circ} \mathrm{C}[18,19]$ and $1100^{\circ} \mathrm{C}[5]$ before the transformation to $\alpha$-TCP takes place. 


\section{Effect of Different Soaking Durations During Calcination}

In order to study the effect of soaking durations, the as-prepared S200 powder was chosen to be calcined at $900^{\circ} \mathrm{C}$ for different soaking durations of 1 hour, 2 hours, 3 hours and 4 hours. The XRD patterns in Figure 3 shows the effect of soaking duration on the synthesis of $\beta$-TCP. The diffraction peaks of the calcined powders at 1 hour, 2 hours, 3 hours and 4 hours matched with the reference patterns of $\beta$-TCP (ICDD 9-169). The crystallite sizes along the (0 2 10) direction of these powders were calculated using the Scherrer equation, whilst the grain sizes were observed using SEM. These sizes were found not to differ much at different soaking durations. Nevertheless, it was found in a separate experiment that calcination temperature has a much significant influence on the crystallite sizes and grain sizes. At a soaking duration of 1 hour, a single-phase $\beta$-TCP can be obtained with the smallest crystallite size of $38.5 \mathrm{~nm}$ and the smallest grain size range of $0.1-0.2 \mu \mathrm{m}$. Henceforth, the optimum soaking duration is maintained at 1 hour compared to 24 hours as reported by Yoshida [5].

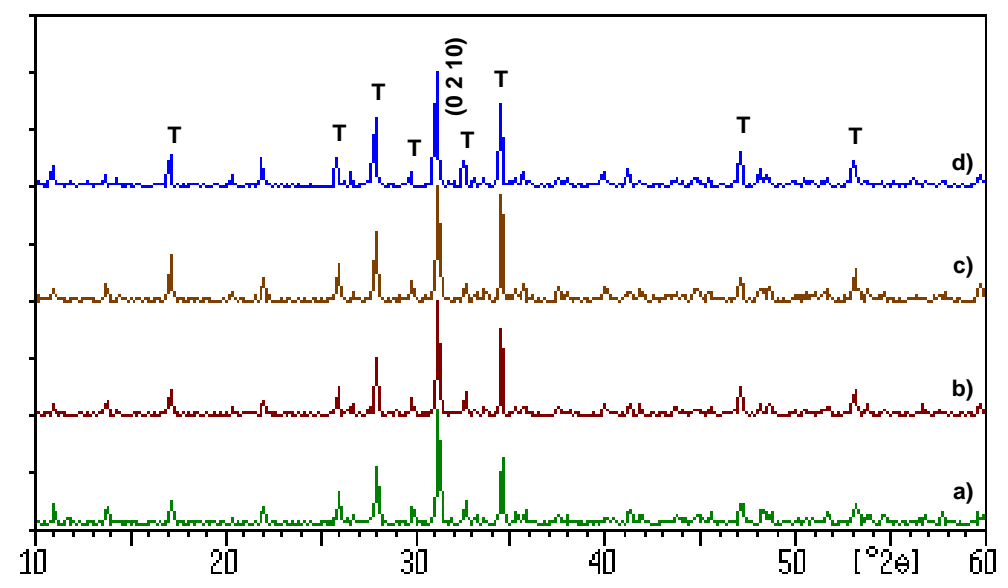

Figure 3. XRD patterns of S200 powder calcined at $900^{\circ} \mathrm{C}$ for different soaking durations [All peaks are assigned to $\beta$-TCP] a) 1 hour, b) 2 hours, c) 3 hours and d) 4 hours.

\section{Effect of Different Mixing Durations}

The as-prepared powders produced from mixing the reactants at $200 \mathrm{rpm}$ for different mixing durations of 1, 2, 3 and 4 hours were calcined at $900^{\circ} \mathrm{C}$ for 1 hour. The uncalcined powders were analysed using XRD and it was revealed that all the as-prepared powders, except for that mixed for 1 hour, produced monetite and HA which transformed to singlephase $\beta$-TCP upon calcination. However, the powder mixed for 1 hour showed incomplete reaction, and the calcined phase consisted of $\beta$-TCP, HA and $\mathrm{CaO}$. Hence, a minimum of 2 hours mixing duration was adopted as the most optimum parameter.

\section{Morphological Analysis Using FESEM}

The morphologies of powders calcined at five different temperatures between $900^{\circ} \mathrm{C}$ to $1300^{\circ} \mathrm{C}$ were observed using the FESEM but only the micrographs for powders calcined at $900^{\circ} \mathrm{C}$ and $1000^{\circ} \mathrm{C}$ are shown in Figure 4 . The powder calcined at $900^{\circ} \mathrm{C}$ shows an aggregated structure with an estimated grain size of $0.2 \mu \mathrm{m}$, whilst that at $1000^{\circ} \mathrm{C}$ still exhibit aggregation but the grain size shows a grains growth of approximately 5 folds due to mass diffusion and the merging of grains to achieve stability. The grain size subsequently showed exaggerated grain growth as the temperature increases to $1300^{\circ} \mathrm{C}$. 
Nonetheless, as shown in Figure 2, the crystalline phase of the powder remains as singlephase $\beta$-TCP even when calcined up to $1300^{\circ} \mathrm{C}$ [20-22].

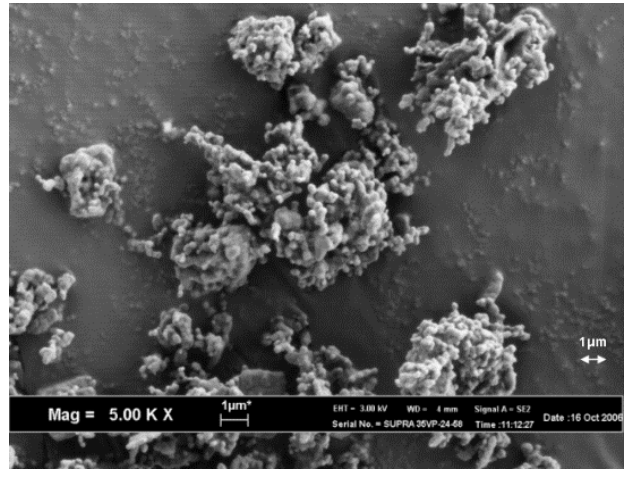

(a)

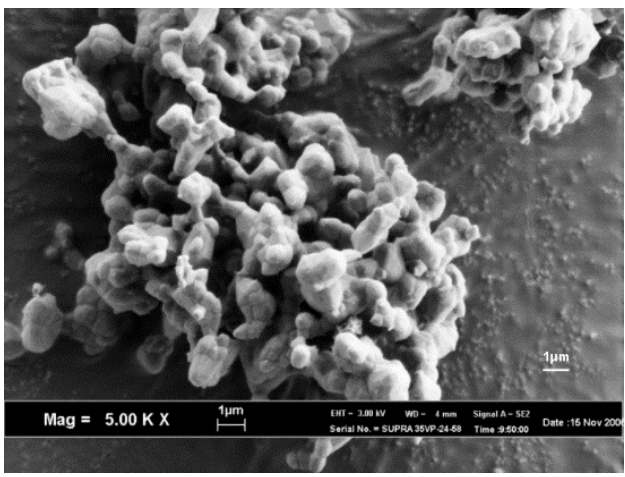

(b)

Figure 4. Morphology by FESEM of S200 powders calcined for 1 hour at (a) $900{ }^{\circ} \mathrm{C}$ and (b) $1000{ }^{\circ} \mathrm{C}$

\section{CONCLUSIONS}

This study has succeeded in synthesising a single-phase $\beta$-TCP using the wet precipitation method, and as a consequence, the most optimum processing parameters have been successfully ascertained. Firstly, this includes the precursor or starting materials used, i.e. calcium hydroxide, $\mathrm{Ca}(\mathrm{OH})_{2}$, and phosphoric acid, $\mathrm{H}_{3} \mathrm{PO}_{4}$, which were previously reported to be mainly used in the direct synthesis of hydroxyapatite, $\mathrm{Ca}_{10}\left(\mathrm{PO}_{4}\right)_{6}(\mathrm{OH})_{2}$. Secondly, the processing parameters have been optimised to ascertain a stirring speed of $200 \mathrm{rpm}$, a calcination temperature of $900{ }^{\circ} \mathrm{C}$, a calcination soaking duration of 1 hour and a stirring duration of 2 hours. The calcination temperature is much lower than that previously reported, and so is the calcination soaking duration. It has also been established that even though there is significant grain growth upon calcination from $900{ }^{\circ} \mathrm{C}$ to $1300{ }^{\circ} \mathrm{C}$, the phase remains thermally stable up to $1300^{\circ} \mathrm{C}$ which is much higher than the transformation temperature to $\alpha$-TCP thus reported so far. These promising features soobtained in this work is attributed not only to the precursor materials being used but also the processing protocols thus adopted. Possible recommendation is to carry out similar studies using different raw materials in order to further understand the significant influences of the processing parameters.

\section{ACKNOWLEDGEMENTS}

The authors would like to acknowledge the financial and technical supports from Universiti Teknikal Malaysia Melaka and Universiti Sains Malaysia.

\section{REFERENCES}

[1] Šupová M. Substituted hydroxyapatites for biomedical applications: A review. Ceramics International. 2015;41:9203-31.

[2] Dorozhkin SV. Calcium orthophosphate bioceramics. Ceramics International. 2015;41:13913-66.

[3] Lee S-J, Yoon Y-S, Lee M-H, Oh N-S. Highly sinterable $\beta$-tricalcium phosphate synthesized from eggshells. Materials Letters. 2007;61:1279-82. 
[4] Choi D, Kumta PN. Mechano-chemical synthesis and characterization of nanostructured $\beta$-TCP powder. Materials Science and Engineering: C. 2007;27:377-81.

[5] Yoshida K, Kobayashi M, Hyuga H, Kondo N, Kita H, Hashimoto K, et al. Reaction sintering of $\beta$-tricalcium phosphates and their mechanical properties. Journal of the European Ceramic Society. 2007;27:3215-20.

[6] Koç N, Timuçin M, Korkusuz F. Fabrication and characterization of porous tricalcium phosphate ceramics. Ceramics International. 2004;30:205-11.

[7] Valletregi M. Synthesis of ?-tricalcium phosphate in layered or powdered forms for biomedical applications. Solid State Ionics. 2004;172:445-9.

[8] Zou C, Weng W, Deng X, Cheng K, Liu X, Du P, et al. Preparation and characterization of porous -tricalcium phosphate/collagen composites with an integrated structure. Biomaterials. 2005;26:5276-84.

[9] Kwon S-H, Jun Y-K, Hong S-H, Kim H-E. Synthesis and dissolution behavior of $\beta$-TCP and HA/ $\beta$-TCP composite powders. Journal of the European Ceramic Society. 2003;23:1039-45.

[10] Cheang P, Khor KA. Thermal spraying of hydroxyapatite (HA) coatings: Effects of powder feedstock. Journal of Materials Processing Technology. 1995;48:42936.

[11] Afshar A, Ghorbani M, Ehsani N, Saeri MR, Sorrell CC. Some important factors in the wet precipitation process of hydroxyapatite. Materials \& Design. 2003;24:197-202.

[12] Saeri MR, Afshar A, Ghorbani M, Ehsani N, Sorrell CC. The wet precipitation process of hydroxyapatite. Materials Letters. 2003;57:4064-9.

[13] Nagai H, Nishimura Y. Hydroxyapatite, ceramic material and process for preparing thereof: Google Patents; 1985.

[14] Schmidt PC, Herzog R. Calcium phosphates in pharmaceutical tableting: 1. Physico-pharmaceutical properties. Pharmacy World \& Science. 1993;15:105-15.

[15] Feng W, Mu-sen L, Yu-peng L, Yong-xin Q. A simple sol-gel technique for preparing hydroxyapatite nanopowders. Materials Letters. 2005;59:916-9.

[16] Xiao XF, Liu RF, Zheng YZ. Characterization of hydroxyapatite/titania composite coatings codeposited by a hydrothermal-electrochemical method on titanium. Surface and Coatings Technology. 2006;200:4406-13.

[17] Kalita SJ, Bhardwaj A, Bhatt HA. Nanocrystalline calcium phosphate ceramics in biomedical engineering. Materials Science and Engineering: C. 2007;27:441-9.

[18] Monma H, Goto M. Behavior of the alpha - beta phase transformation in tricalcium phosphate. Journal of the Ceramic Association, Japan. 1983;91:473-5.

[19] Champion E. Sintering of calcium phosphate bioceramics. Acta Biomaterialia. 2013;9:5855-75.

[20] Nikaido T, Tsuru K, Munar M, Maruta M, Matsuya S, Nakamura S, et al. Fabrication of $\beta$-TCP foam: Effects of magnesium oxide as phase stabilizer on its properties. Ceramics International. 2015;41:14245-50.

[21] Li HC, Wang DG, Chen CZ, Weng F, Shi H. Influence of different amount of Na $2 \mathrm{O}$ additive on the structure, mechanical properties and degradability of bioactive wollastonite. Ceramics International. 2016;42:1439-45.

[22] Latifi SM, Fathi M, Varshosaz J, Ghochaghi N. Simultaneous structural and surface modifications of nanophase hydroxyapatite for improving its dissolution and bioactivity. Ceramics International. 2016;42:6355-9. 